\title{
メカトロニクス教育考
}

\section{梶谷 誠**}

A View of Mechatronics Education / Makoto KAUITANI

Key words: mechatronics, mechanical engineering, engineering education,

curriculum, mechatronic engineers, university

\section{1. ま え がき}

メカトロニクスという言葉が世に出てから，約 20 年を 経過し，世界にも通じる共通語となり，その概念もほぼ定 着した感がある。教育の面からも，大学・高専の機械系学 科を中心に，メカトロニクスをカリキュラムに取り入れる ところが増大し, 最近では汪とんどの大学・高専に広がっ ている，そればかりか，工業高等学校にも電子機械工学科 などのメカトロ系の設立が相次いだ。1980年代には，企 業内の機械系技術者の再教育としてメカトロニクス講座が 盛んであった。一方, 諸外国でも, 石油ショック以後の日 本の産業構造の転換之経済発展の秘密の一つがメカトロニ クスにあることに気づき，メカトロニクス教育を導入した ところも多い.

ところで, 以前から指摘されていた若者の理工系離れの 潮流の中で，いわゆるバブル崩壊による厳しい経済状況が 発生し, 予想をはるかに超壳る円高基調による製造業の低 迷，海外シフト，企業の新規採用の急激な縮小など，技術 者養成の基礎的基盤が憂慮すべき環境にある。数年前まで は, ぞんな学生でも数をそろえさえすればよいといわんば かりの新卒者の採用を展開していた企業が，昨年から手の ひらを返したように，今の学生は基礎学力がない，たより ないなどと言って厳しく絞り込んでいる。一方，大学では 入学生の学力不足, やる気のなさなど質の低下を嘆き, そ のために必然的に生じる過重な教育労働の負担に疲労困ぱ

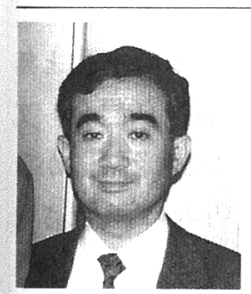

* 原稿受付平成 7 年 6 月 23 日

** 正会員電父通信大学電気通信学部（調布市 調布ヶ丘 1-5-1)

1971 年東京工業大学大学院機械工学専攻博士 課程修了，工学博士. 歯車の計測システム, 磁 気スケール, ロータリエンコーダの自動校正シ ステム, 楽器演奏ロボット, 建設作業用移動口 ボットなどの開発・研究に従事
いの態である。

上記の不幸な現象にはいろいろ要因があり，われわれ教 育機関関係者のみでは対処できない複雑な問題をはらんで いる。いずれにせよ，わが国の経済基盤は依然として製造 業にあり，技術立国としての要は技術者の養成，とりわけ メカトロ技術者への期待は大さい。

本稿では，まず大学に打ける工学教育，特にメカト口的 教育感について簡単に私見を述べ，ついでわが国执よび諸 外国のメカト口教育の実状を若干紹介する。

\section{2. 大学における技術者養成と教育改革}

工学教育については，すでに多くの識者が多数の見解を 随所で披露して和り，考光方は出尽くしたと言えよう。筆 者も過去いくつかの私見を発表したものの兄 3), 今読久返 して自らの実践結果と対比させたとき，その腑甲斐なさに 赤面を禁じ得ない。にもかかわらず，現場でのつきぬ悩み を打開する糸口として，十分な推敲のないままの乱暴な議 論ではあるが，大学に括ける工学教育の問題のうち, 2,3 の問題点の指摘とその対策を模索してみる.

（1）理屈は後だ，まず体験させよう.

子供快本来，新しい発見や創造に喜びを感じる本性を 持っている. 理工科離れの第一の原因はその体験の欠如で ある。昨今の工学系の学科の入学生にも, 自分で刃物を 持って括もちゃを作ったりするなど主体的遊びの体験が貧 弱になっている，また，総じて工学系で勉学をする動機が 希薄である. このよらな現状のなかで, 従来の理工系教育 のオーソドックスなスタイル，すなわちいわゆる基礎から 応用へとカリキュラムを進行していく方法では, もはや多 くの学生たらの自発的な勉学意欲を喚起できないであろ ら。そこでまず，入学したばかりの学生に自分が興味を 持っていることを，実験でも創作でも，いきなりやらせて 
みてはどらであろう。まず体験ありきである．そこで発生 するトラブルから, 問題を発見し, その解決に必要之認識 した後にその授業を受けることにすれば，教室の雾囲気は がらっと変わるに違いない。もちろん，これにはいろいろ な設備と人手が必要で, 実現は容易ではない.

筆者の属する学科（電気通信大学機械制御工学科）で は，昨年度から若干のカリキュラム改訂を実施し，ほぼ上 述の基本的考光方に沿った方法として，次の 3 つのことを 実施あるいは計画している.

(1) 1 年前期の「基礎セミナー（全教官担当）」の授業 で，学生をグループに分け，グループごとに毎週 1 回 1 研 究室を訪問し, 先生や研究室の学生から, 研究の話を聞い たり，実験室を見学する.

(2) 従来 3 年後期で行っていた「メカトロニクス（筆者 担当)」の授業を 1 年前期に移し, 学生が親しみのある題 材（昨年は主として CD）を取りあげ，その仕組みをやさ しく解説しながら，そこに含まれているさまざまな技術と それに関連する学問や授業を紹介している.

(3) 現在, 学科内に「ロボメカ工房」を設置すべく, 山 藤教授を世話人として準備中である．この工房では，希望 する学生が自由に自分のアイデアを試したり, 実験でき る. 教官はアドバイザとして相談に応じる. 本学科に入学 する学生の多くはロボットを作りたいと言っているので, その意欲が失われないらちに，さらにェンカレッジすると ともに，口ボットを作るためにいかに多くの基礎技術が必 要で, そこにもたくさん面白い課題があることを知っても ら扔うといらのがねらいである.

（2）教室から黒板を撤去せよ

教室に教壇と黒板があり, 先生と生徒が向かい合って授 業を進めていくこのスタイルはいつごろから始まったか 知らぬが，実に古くさい，最近は，OHP，VTR，コン ピュータが設置された教室も増え，授業の方法も多彩に なってきた. マルチメディア時代の到来に向けて当然のこ とである. 今後, マルチメディアによるCAI 教材の開発 を進めていけば，理工系の通常の講義は全廃できるであろ 5. 先生は, 決まった時間に教室に行って講義することは なく，個々の学生とマンッーマンのアドバイザーとして付 き合うなかで，自然に学生の全人教育を担らことにもなろ 5 .

\section{（3）入学式と卒業式を廃止せよ}

留学生, 社会人, 夜間コース, 生涯教育など在学する学 生も多様になってきた. 4 年制の学部学生に扣いてすら, 入学動機, 目的, 学力, 既修科目等ますます多様化しつつ ある. このような変化に対応して, 大学の修業年限を撤廃 して，何年かかららが基準に達した者がそのときに卒業し ていくよらにすればよい，企業も 4 月に一斉に新卒を採用 する方式もなくなり, 大学も就職の世話などしなくてよく なるだろら．教育がやりにくいということもあろらが, (2) で述べた新しいマルチメディア CAI システムが軌道
にのれば，そんな心配もなくなるであろう.

\section{3. 教育的視点から見たメカトロニクスの本質}

メカトロニクスを教育するとき，何をその根幹の思想と し，彼らにどのような心構えを期待すべきであろらか。す ちろん，先にも述べたようにまず具体的な製品を通して興 味を持たせ，自発的な創造意欲をかき立て，それを実現す るに必要な基礎的な知識や手法を理解し適用できる能力を 育てることが当面の目標となる。 しかし，具体的な知識や 手法は日々進歩し変化する. もっと普遍的なバックボーン を形成しておく必要があろう。そこで，技術の目的は付加 価値の付与にあるとし, 価値に関する次の 3 つの観点をメ カトロ 3 大則として提唱したい。

（1） 情報即価值

メカトロニクスは, 社会がその発展の必然として高度情 報化社会へ移行していく中で，機械と情報のかかわりの 3 つの側面 ${ }^{4}$ を通して, 機械と情報の融合, 一体化が要請さ れ，それを実現する技術として誕生したものである ${ }^{5}$. 従 来, 工業 3 大要素である物質, エネルギー, 情報のらち, 主に物質と土ネルギーを対象としていた機械技術に情報が 融合し，機械システムの価值が飛躍的に向上した.

さて, 付加価値とはなにか。ここで, 次式の関係の成立 を仮定する。

付加価値 $=$ 物質 $($ 実体 $) \times$ 情報

すなわち，価値は物質（実体）と情報のかけ算であり，ど ちらが久けても価值はゼロになる，一方だけでは価値は得 られない，たとえば，扮米はそれが食料であることを含め て，その料理法などの知識（情報）があるからこそ価値を 持つのであり, これらの知識が無い人にとっては何も価値 がない，逆に，ぞんなに貴重な情報があろらと，現実にお 米が存在しなければ，だれもその価值を享受できない。言 い換えると，付加価値を生むのは，人間の知的活動によっ て生産される情報のみであるが，付加されるべき実体がな いところでは実を結ばないのである，バブル経済は，実体 のないところのみかけの価値を錯覚した結果だったとい兄 よう.

以上の上らに，メカトロ化のみならず，技術の本質は情 報による付加価値の創出にあるからこそ, 技術開発, 研究 開発, 創造性が重要なのである. また, 情報は物質やエネ ルギーと異なり，無限に生産でさる一方で，その新鮮さ

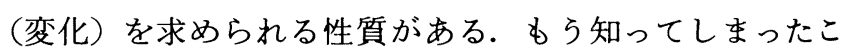
とでは, 高い対価は得られないのである.

（2）融合による価値増幅

メカトロニクスが日本で生まれたのは, 日本の文化と無 関係ではない. 日本文化の特徵の一つは, 融合 (混合) 文 化にある. 古くは中国から，近世になっては欧米諸国から 貪欲に文化を輸入し, 日本古来の文化と巧みに融合させ て, 独特の文化を創造してきた。 
メカトロニクスは，機械，電子，情報など異種の技術を 融合させたものである．異種のものを融合することによっ て新しい価値を創出すること，専門分野にこだわらず，必 要とあれば化学でもバイオでも自分の技術に取り入れて融 合する心構えこそメカトロ精神なのである.

(3) 矛盾の価値化

日本でメカトロニクスが芽を吹いたきっかけは，1973 年 10 月の第 1 次石油ショックであった. 天然資源の乏し い日本は，資源を使わずに付加価値の高い製品を作ること を求められた。このときの危機感が，技術革新を生んだ. いまや，世の中は矛盾が多いが，矛盾を解決するところに 価値が生まれる，矛盾を見つけたとき，価値の種を発見し たと喜び，その解決に生き甲斐を感じる技術者をメカトロ ニクス技術者と呼びたい.

\section{4.メカトロニクス教育の変遷と現状}

IC の出現に始まる 1960 年代は，エレクトロニクスの躍 進めざましく，高度経済成長を支える技術者養成のため， 電子工学科を中心とする理工系学科が各大学に次々と新設 された. 電気通信大学では 1959 年の電子工学科に続き, 1960 年に通信機械工学科が設立されている，表 1 は，同 学科の開設当時のカリキュラムである. その学科概要に は, 「電気通信工学と機械工学とを別々に切り離さず，こ れを一体として取り扱い，両者の融合をはかりながら教育 し，機械工学・電気通信工学を単独に習得した者よりも広 い工学的視野を有し, 両工学の中間の新しい分野を開拓し ていけるよらな技術者・研究者を教育する」とある．正に

表 1 電気通信大学通信機械工学科 (1960 年)のカリキュラム ( ) 内は単位数

\begin{tabular}{|c|c|c|}
\hline 種 & 類 & 授 業 科 \\
\hline \multirow[b]{2}{*}{ 必須科目 } & 電気通信系 & $\begin{array}{l}\text { 電磁気学及び演習 (7), 電気回路学及び } \\
\text { 演習 (7), 電気測定学 (4), 電子回路学 } \\
\text { (4), 工学実験 第 } 1 \text { (4), 電気 音響 学 } \\
\text { (4) }\end{array}$ \\
\hline & 機械工学系 & $\begin{array}{l}\text { 材料力学 (4), 機械設計法 (4), 設計お } \\
\text { よび製図 (5), 工作実習 (2), 機構学 } \\
\text { (4), 精密加工学 (4), 弾性括よひ塑性 } \\
\text { 力学 (4), 材料の性質 (4), 工学実験第 } \\
2 \text { (2), 輪講または演習 (2), 卒業研究 } \\
\text { (6) }\end{array}$ \\
\hline \multirow{3}{*}{ 選択科目 } & 電気通信系 & $\begin{array}{l}\text { 通信部品論 (2), 電子応用計測 }(2) \text {, 電 } \\
\text { 子管工学 (4), 半導体工学 (4), 有線工 } \\
\text { 学 (4), 無線工学 (4), 電力工学 (4), } \\
\text { ヘルス工学 (2), 情報理論 (4), 電子計 } \\
\text { 算機 }(2) \text {, 自動制御論 (2) }\end{array}$ \\
\hline & 機械工学系 & $\begin{array}{l}\text { 工業熱力学 (2), 振動論 (4), 非線形振 } \\
\text { 動論 (2), 機械材料 (2), 移動論 (2), } \\
\text { 応用光学 (2) }\end{array}$ \\
\hline & その他 & $\begin{array}{l}\text { 経営学総論 (2), 生産管理 (2), 品質管 } \\
\text { (理 (2), 統計力学 (2), 量子力学 (2) }\end{array}$ \\
\hline
\end{tabular}

現在のメカトロ教育の先駆けである. 当時はまだ機械屋， 電気屋が歴然と一線を画していたころで，必ずしも世間の 理解を得ることができず，苦労も多かったと聞く6).

1970 年後半から 1980 年代に入り，メカトロニクスが成 熟してくると, 名古屋大学の電子機械工学科の創設など大 学に打けるメカトロニクス技術者の養成も本格的になっ た.さらに, 1991 年に大学設置基準の改訂（いわゆる大 綱化）が実施されるなどの大学改革の大きな流れのなか で, 機械工学系学科の改組も盛んで, 将来性と魅力のある 名称に変更するとともに，メカトロ教育の一層の充実が図 られている.

一般に，機械系学科にメカトロニクス教育を導入しよう とするとき，その進展をカリキュラム編成の面からみる と, 次の 3 段階で進んでいく.

[第 1 段階］従来の機械工学（精密工学）の中に，電子工 学や情報工学（コンピュータ）関連の基礎科目を加え，そ れらの担当を主として他学科や非常勤の専門家に㹉願いす る.

[第 2 段階］従来の機械工学系科目を整理し，電子工学や 情報, ロボティクス関連の科目を加え, 学科の教官が担当 する.

[第 3 段階］メカトロニクスを新しい工学（技術）体系と とらえて，機械，電子，情報という枠組みを取り払った新 しい内容のテキストを創設する.

近年, 多くの大学では, 機械系学科の中にメカトロ系の 人材が充実したため，すでに第 2 段階に達し，第 3 段階へ の試行が始まっている.

最近 3〜 4 年の間に, 大幅な学科改組を実施した東北大 学, 東京大学, 東京工業大学などでは, 新しい機械系学科 の在り方を総合的に検討し, 情報, システム, 制御, セン サ，アクチュエータ，ロボティクス，電子回路などを大幅 に取り入れ，一部上記第 3 段階への試行や転換が見られ $る^{7) 8}$. しかし，特に従来の機械系の科目については，ま だまだ今後の課題として工夫の余地が残されているような 気がする.

さて，従来の機械系の教育が，もの造りを目標とすると しながらも，実際は解析的手法の学習が中心になってい た.これに対して，メカトロニクス教育は，最終的にシス テムを作り上げて機能を実現させること，すなわちシンセ シスの能力の付与を目指するのであるとの認識が強い，加 えて，すでに 2 章で指摘した「理屈は後だ，まず体験させ よう」といら動機付け教育の必要性と創造性教育の観点か ら，自主的な設計・製作，実験（演習）などの授業に，新 しいュニークな試みが行われている.たとえば，東京大学 機械情報工学科の学生実験では, 学生全員が 1 人 1 台の ボードコンピュータを製作し，そのプログラミング演習, 周辺回路のアナログ，ディジタル回路の製作と実験を行 5. その後, 自分で企画したプロジェクト（ボードコン ピュータを応用したシステム）を完成させ，発表させ 
る . 東京工業大学機械宇宙工学科では, 実習による実感 教育を実施する「マシン創造センター」を設けて, 創造授 業を実施している ${ }^{10)}$.たと学ば， 2 年次前期に，実際のい ろいろな製品を分解させ，その機能，メカニズム，材料な どを解説し，確かめ，また組み立てるなど，まず機械に手 を触れさせ，親しませ興味を持たせることを主眼としてい る. 3 年次には「大道芸ロボット」をグループごとに設計 製作させ，発表会を一般公開で行っているのは有名な話で ある. 早稲田大学機械工学科でも，3 年次の学生が $12 \sim 15$ 人ごとに各研究室に分かれて，ロボットコンテストを行ら など主として実習的な授業を行う「ェンジニアリングプラ クティス」の評判がよいといら ${ }^{11)}$ 。このような，実習的授 業の充実は今後大いに拡大していくであろらが，学生がこ の体験を踏まえて, 確実な体系的考方方を身につけ，しか あ柔軟な思考態度を一層高められるよらなバックアップ体 制が今後の課題となるであろら.

\section{5. 海外のメカトロ教育}

ヨーロッパでは, 1980 年中葉から急速にメカトロニク スへの関心が高まり, すばやく大学の正規のコースを設け たところもある. 英国では 1980 年後半から, Loughborough University, Glasgow College や Lancaster University などでメカトロニクスコースが設けられている.さら に，驚くべきことに，同国の The Open University（日本 の放送大学に相当）にも Mechanical Engineering, Electronics and Artificial Intelligence をキーワードとするメ カトロニクスコースがあり，多様なプログラムを用意して いる．英国では，設計工学 (Engineering Design) の立場 からメカトロニクスを構成しょらとする傾向が強い. ラン カスター大学では Engineering Design Centreを中心にメ カトロニクスコースを運営している.

フィンランドは1987から 3 年間, メカトロニクスに関 する国家研究プロジェクトが産業界, 研究機関, 大学との 共同で大々的に実施された. メカトロ教育にも力を入れ, 各工科大学にいろいろなメカトロニクスのトレーニング コースが置かれている. スウェーデンの王立工科大学で は, 1984 年にマイクロコンピュータ応用システムの設計 というメカトロニクスの講座を開設した.これは一種のプ ロジェクト実習であるが，企業との契約によって行われ， その結果が企業で実際に役立つよう期待される.

最近訪ねたイタリアのトリノ工科大学機械工学科のメカ トロニクスの授業は，講義と実習がそれぞれ 1 週 4 時間 (週 2 回), トータルで 14 週である. 実習は計算と実験を 週 2 時間ずつ（週 2 回）行い, 最後にレポートにまとめて
提出する.トリノ大学の卒業生を採用している現地の日本 人マネージャから, トリノ大学の卒業生は採用してすぐに 仕事ができるのに，日本の大学の卒業生は訓練しなければ 使えないのはどうしてだろらと聞かれて, 日本の大学教育 と欧米のそれの違いを改めて思い知り, 大学教育の国際化 の必要性を痛感した。

アジアでもメカトロニクスは浸透しつつある. 中国の古 都，四川省成都にある中国電子科技大学には，かなり以前 から電子機械工学科が設置され, メカトロニクス教育に力 を入れている.

\section{6. あ と がき}

長年のメカトロニクスの発展と普及で, メカトロニクス という言葉には目新しさが無くなったとはいえ, 依然とし てわが国の産業を支える戦略的技術である，そして，技術 を支えるのは技術者であり，その教育の質が問われるよう になってきた。この際，人材供給と活用の両者が集まる学 会のような場で, 長期的視点から今後の技術者育成の在り 方を提言することも必要ではないだろらか。

本稿で取り上げたメカトロ教育の現状は，たまたま筆者 の手元にあった資料を引用したものなので，少々古くなっ ていたり，紹介しそびれたものもあることを，ご容赦いた だきたい

\section{文献}

1）梶谷 誠：メカトロニクス教育, 精密機械， 50, 1 (1984) 215 .

2）梶谷 誠：メカトロニクス時代の設計製図教育, 設計製困, 23, 150 (1988) 38.

3）暒谷 誠：大学におけるロボット・メカトロニクスの研究と教 育，日本ロボット学会誌，8，1，(1990） 83.

4）梶谷 誠：メカトロニクスの概念, 精密工学会誌, 52,7 (1986) 1110.

5）暒谷 誠：高度情報化社会とメカトロニクス，日本機械学会 誌，89，810（1986） 507 .

6）梶谷 誠：メカトロニクス教育の先駆者を訪ねて，精密工学 会誌，52，7 (1986) 1146

7）井上博允：東大機械情報工学カリキュラム，日本機械学会口 ボティクス・メカトロニクス講演会 '93，No．930-40（1993） 625 .

8）箱守京次郎ほか：東北大学機械系に扰けるロボティクス・メカ トロニクス教育, 日本機械学会ロボティクス・メカトロニクス 講演会 '93，No. 930-40（1993）629.

9）稲葉雅幸：東京大学機械情報工学科自主プロジェクト型学生 実験, 日本機械学会ロボティクス・メカトロニクス講演会' 93 , No. 930-40 (1993) 644.

10）広瀬茂男：実習・実感・創造教育の試み，日本機械学会口ボ ティクス・メカトロニクス講演会' 93 , No. 930-40 (1993) 636 .

11）营野重樹：早大機械工学科に打けるロボメ力関連教育，日本 機械学会ロボティクス・メカトロニクス講演会'93, No. 930-40 (1993) 642. 